\title{
PROPERTIES AND CONSTRAINTS OF RED.YELLOW AND VOLCANIC ASH SOILS PLANTED TO ROOTCROPS IN THE PHILIPPINES
}

\author{
ANABELLA B. TULIN \\ Visayas State University, Visca, Baybay, Leyte
}

\section{ABSTRACT}

Soil samples representing highly weathered Red-Yellow and Volcanic Ash soils were collected from 45 pedons of different rootcrop producing provinces in the Philippines. This research was conducted to provide a comprehensive data on the properties and constraints of Redyellow and Volcanic Ash soils planted to rootcrops through determination of the soils' various morphological, physical, and chemical properties. Some of the identified soil constraints associated with Red-Yellow and Volcanic Ash soils planted to rootcrops include : low organic matter, soil acidity, Al toxicity, low CEC, low amounts of exchangeable bases such as $\mathrm{Ca}, \mathrm{K}, \mathrm{Mg}$, and $\mathrm{Na}$, low $\mathrm{P}$ avallability, high clay content, and highly compacted soils. The results of this research showed strong evidence on the existence of morphological, physical, and chemical constraints in Red-Yellow and Volcanic Ash soils that are planted to rootcrops in large areas in the Philippines.

KEYWORDS: Soil constraints, soil fertility, rootcrop production 


\section{INTRODUCTION}

In the Philippines, most of the volcanic ash soils that are used for crop production are classified under the order Ultisols, Andisols, Inceptisols, and Alfisols (Otsuka et al., 1988). Generally, they are referred to as the RedYellow soils (Ultisols and Alfisols) and Volcanic ash soils (Andisols). These soils are usually dominated by $1: 1$ clay minerals such as kaolinite and halloysite, oxides and hydrous oxides of iron and aluminum in crystalline and amorphous forms and amorphous aluminosilicates or allophane (Bautista-Tutin and Inoue 1997; Bautista-Tulin 1995). The colloidal components of these soils are dominated by variable charge colloids (Theng 1980; Tulin 2000). In humid tropical areas like the Philippines, where these soils dominated by colloidal materials abound, the soils are exposed to extensive leaching of bases due to high amount of rainfall which is prevalent in the area. This situation poses a major fertility problem in managing highly weathered variable charge soils in the tropics especially if we used these soils for crop production. One of the major problems associated with Andisols or volcanic ash soils in the Philippines is the small amount of $\mathrm{P}$ and high $\mathrm{P}$ - fixing capacity of the soil (Bautista-Tulin et al., 1996).

In the global food system, roots and tubers have myriad and complex parts to play in feeding the world for the coming decades. Far from being one sort of crop that serves one specific purpose, they will be many things to many people. (Scott et al., 2000). In some cases, they will mean the difference between subsistence and in achieving an improvement on the economic ladder; to others, they will mean the difference between survival and starvation. This is because rootcrops are found in a wide variety of production systems and do well under various levels of management, from low-input to high input systems aside from having a wide variety of uses. From a global perspective, sweetpotato and cassava could be processed as food, feed and, starch-derived products. Potato and yam are used largely as food in the fresh forms although recently, there had been high demands for yam in industry especially the purple variety which are processed into powder forms and used in various food products. 
The growth and yield of rootcrops are very much dependent on the soil where it is grown. The soil serves not only as a medium for plant growth but it also acts as a reservoir of essential nutrients for rootcrops. The importance of soil reservoir in rootcrop production is greatly intensified if we consider the capacity of rootcrops to extract large amounts of nutrients from the soil for their growth and development. This problem is aggravated by the limited availability of lands intended for agriculture. This forces our farmers to continuously. plant their crops on the same piece of land for years without proper management. This situation led to fast depletion of available nutrients that are inherently present in the soil. it is more serious for rootcrops planted to such kind of soils due to their capacities to extract higher amounts of nutrients as compared to other crops. Lack of necessary inputs needed to maintain the fertility of soils further complicates the problem and this is usually encountered by our subsistence farmers.

In tropical Latin America, over $50 \%$ of cassava is grown on Ultisols, Oxisol, and Inceptisols which are all characterized by extreme acidity and low levels of available N, P, and K. In these places, fertilizers are seldom applied to the crop since farmers generally believe that the crop does not respond to fertilization (Howeler 1985). However, numerous trials conducted by FAO throughout the world between 1961 and 1977 (FAO 1980) indicate that cassava is as responsive to fertilizer application as most other crops that traditionally are applied with fertilizer and this practice is found to be economical (Howeler 1985).

In sweetpotato, some of the reported constraints affecting its production include saline and alkaline conditions which are unfavorable for its growth (Rasco and Villamayor 1986). Furthermore, pH below 4.5 and above 8.0 are also detrimental to sweet potato. Plant nutrition also plays a major role in sweetpotato production. Deficiency symptoms were observed in the leaves, stems, and roots when N, P, K, $\mathrm{Mg}, \mathrm{Ca}, \mathrm{S}$, and $\mathrm{Fe}$ were below critical levels (Tulin et al. 1999; Tulin 2000). 
In the Philippines, no comprehensive data are available at present on the various soil constraints affecting the productivity of rootcrops in some major rootcrop producing areas of the country. This causes a lot of problems to researchers, scientists, extension workers, and development planners in making land assessment for rootcrop production. A nationwide survey conducted by Bautista and Armecin (1990) among subsistence rootcrop farmers indicated very low rootcrop yields which ranged from 1 to 5 tons/ha- ${ }^{-1}$ for sweetpotato unfertilized farms. Data gathered on the previous cropping prior to the interview also indicated very low rootcrops yields which $<5$ tons ha- ${ }^{-1}$ for sweetpotato and other minor rootcrops and between 5-10 tons ha-1 for cassava which are still below the attainable yields of rootcrops. This finding was further supported by the report of Villamayor and Amante (2000), which indicated the very low productivity of sweetpotato in the upland environment. The average yield is $4-6$ tons/ha- ${ }^{-1}$ in Albay and even lower $\left(3-5\right.$ tons/ha-1 ${ }^{-1}$ in Leyte.

This research was conducted to provide a comprehensive data on the properties and soil constraints of Red-Yellow and Volcanic Ash soils planted to rootcrops in the Philippines. Specifically this paper focused on the possible causes of low rootcrop productivity on different rootcrop producing areas based on soil's morphological, chemical, and physical properties.

\section{MATERIALS AND METHODS}

\section{Collection of Soil Samples}

Soil samples taken from 45 soil pedons and representing 36 soil series were collected from different rootcrop-producing provinces of Luzon and the Visayas islands in the Philippines. The identification of rootcrop areas surveyed was taken from secondary data of soil survey reports of different provinces in the Philippines, NEDA statistics, and Philrootcrops' report. The various pedons sampled in Luzon include 2 pedons in Sorsogon; 4 pedons in Albay; 4 pedons in Carnarines Sur; 3 pedons in Tarlac; 2 pedons in Benguet; 3 pedons in Ifugao; 1 pedon in La Union; 
3 pedons in Pangasinan, and 3 pedons in llocos Norte. In the Visayas, 2 pedons were characterized in Samar; 7 pedons in Northern Leyte; 7 pedons in Southern Leyte; 2 pedons in Cebu (Camotes island); and 2 pedons in Negros Occidental.

\section{Morphological Characterization}

Soil pits measuring $1 \mathrm{~m}$ wide and $1 \mathrm{~m}$ depth (or more depending on the depth of water table or parent material) were dug for each pedon for detailed morphological characterization based on soil survey manual (Soil Survey Staff 1993). For morphological characterization, the following soil properties were described as they occur in the field: soil series, location, vegetation and land use, percent slope, parent material, date collected, authors of the description, horizon depth, soil color (field moist), soil structure, consistency, plasticity, and presence of roots.

\section{Physical and Chemical Characterization}

Soil sample of $1 \mathrm{~kg}$. were collected for each identified soil horizon and these were brought to the laboratory for physical and chemical characterization. The different soil physical properties determined include the following: texture ( $\%$ sand, silt, and clay), $\%$ moisture content, $1 / 3$ bar moisture content, and 15 bar moisture content. The different chemical properties gathered include the following: soil pH (in $\mathrm{H}_{2} \mathrm{O}$ ), percent organic matter (\%O.M.), total acidity, exchangeable aluminum (Al) and iron (Fe), available P (Bray \#2), exchangeable sodium (Na), potassium $(\mathrm{K})$, calcium $(\mathrm{Ca})$ and magnesium $(\mathrm{Mg})$, percent base saturation ( $\%$ B.S.), and cation exchange capacity (CEC). The procedures for soil analysis by Hamazaki and Paningbatan were followed in the analyses (TARC 1988). 


\section{RESULTS AND DISCUSSION}

\section{Morphological Characteristics of Rootcrop Soils}

Some of the important morphological characteristics of rootcrop soils determined in this project include soil color, horizonation, texture, structure, consistency, and the presence of roots and pores. The morphological descriptions reflect some important properties of the soil as seen in the field. A brief summary of the important morphological characteristics of the areas surveyed are presented in Table 1.

\section{Soil color}

Soil color is indicative of the type of minerals which composed the soil and the present and past conditions of the soil. It gives us an idea on the degree of weathering the soil has undergone and the prevailing fertility status of the area sampled although the results needs to be further validated by chemical analyses. Results presented in Table 1 showed that almost all the soils sampled exhibited the characteristic color of Red-Yellow and Volcanic Ash soils which are characterized by color hue ranging from $2.5 \mathrm{YR}$ to $10 \mathrm{YR}$. Hamazaki and Paningbatan (1990) classified the Red-Yellow soils in the Philippines into different soil groups which include the red soil, yellow soils, dark brown soils, terra-rossa-like soils, and terra-fusca-like soils. Red soils are defined as those soils having an argillic $B$ horizon wricu nas a hu $;$ of 5 YR or redder than 5 YR and base saturation of less than $50 \%$ (by NF. OAc) in at least some pats of the $B$ horizon within $125 \mathrm{~cm}$ of the surface. Yellow soils, on the other hand, are defined as soils having an argillic horiz $n$ which has a hue yellower than 5 YR and a base saturation of less than $50 \%$ (by $\mathrm{NH}_{4} \mathrm{OAC}$ ) in at least some paris of the $B$ horizon within $125 \mathrm{~cm}$ of the surface. Red-Yellow soils include the following soil series: Annam, Tigaon, Alaminos, Bolinao, Faraon, Bauang, Banyan, Catbalogan, Tacloban, Palo, Palompon, Maasin, Guimbalaon, Langa, and Mayoyao. 
Table 1. Some morphological properties of the A and B horizon of the Red-Yellow and Volcanic Ash soils planted to roolcrops in the Philippines

\begin{tabular}{|c|c|c|c|c|c|c|}
\hline $\begin{array}{c}\text { Soil } \\
\text { Series }\end{array}$ & $\begin{array}{c}\text { Soli } \\
\text { Horizon }\end{array}$ & $\begin{array}{l}\text { Depth } \\
\text { (cr) }\end{array}$ & Soil Color & $\begin{array}{c}\text { Soil } \\
\text { Texlure }\end{array}$ & Structure & Consistency \\
\hline Annam & $\begin{array}{l}A \\
B\end{array}$ & $\begin{array}{c}0-20 \\
20-43\end{array}$ & $\begin{array}{l}\text { s B (7.5YR } 4 / 4) \\
\text { SB (7.5YR 5/6) }\end{array}$ & $\mathrm{CL}$ & $\begin{array}{l}\text { WG } \\
\text { s SB }\end{array}$ & $\begin{array}{l}f P S \\
\text { IPS }\end{array}$ \\
\hline Banyan & $\begin{array}{l}A \\
B\end{array}$ & $\begin{array}{c}0-16 \\
\text { Below } 27\end{array}$ & $\begin{array}{l}\mathrm{B}(7.5 \text { YR } 414) \\
\mathrm{d} B(7.5 \text { YR } 3 / 4)\end{array}$ & C & $\begin{array}{c}m S B \\
m S B\end{array}$ & $\begin{array}{l}f \text { NPNS } \\
\text { fPS }\end{array}$ \\
\hline Bauang & $\begin{array}{l}A \\
B\end{array}$ & $\begin{array}{c}0-9 \\
9-36\end{array}$ & $\begin{array}{l}\text { By (10YR 6/6) } \\
\text { By (10YR } 6 / 8)\end{array}$ & C & $\underset{m S B}{m G}$ & $\begin{array}{l}\text { P.S } \\
\text { PS }\end{array}$ \\
\hline Bolinao & $\begin{array}{l}A \\
B\end{array}$ & $\begin{array}{c}0-23 \\
23-42\end{array}$ & $\begin{array}{l}\mathrm{d} R B\left(2.5 Y R R^{3 / 4}\right) \\
\mathrm{dRB}(2.5 Y R 3 / 6)\end{array}$ & $\mathrm{C}$ & $\begin{array}{l}W G \\
S S B\end{array}$ & $\begin{array}{l}\text { fsPS } \\
\text { PNS }\end{array}$ \\
\hline Castilla & A & $0-12.5$ & $\mathrm{~dB}\left(7.5 \mathrm{YR}^{3 / 4}\right)$ & $\mathrm{CL}$ & $w G$ & INPS \\
\hline Casugiran & $\begin{array}{l}\mathrm{B} \\
\mathrm{A}\end{array}$ & $\begin{array}{c}50 \text { below } \\
0-9\end{array}$ & $\begin{array}{c}\mathrm{dB}(7.5 Y R \quad 4 / 4) \\
\mathrm{dB}\left(7.5 Y \mathrm{Y}^{3} / 4\right)\end{array}$ & $\mathrm{CL}$ & $\begin{array}{c}m S B \\
W G\end{array}$ & $\begin{array}{l}\text { PNS } \\
\text { fNPS }\end{array}$ \\
\hline Calbalogan & $\begin{array}{l}\text { B } \\
\text { A } \\
\text { B }\end{array}$ & $\begin{array}{c}31-100 \\
0-6 \\
17-34\end{array}$ & $\begin{array}{r}\text { dRB(7.5YR 3/3) } \\
\text { VdGB(10YR 3/2) } \\
\text { dyB (10YR 5/6) }\end{array}$ & $\mathrm{CL}$ & $\begin{array}{c}s P \\
W G \\
m S B\end{array}$ & $\begin{array}{l}\text { PNS } \\
\text { fPS } \\
\text { PPS }\end{array}$ \\
\hline Faraon & $\begin{array}{l}\text { A } \\
B\end{array}$ & $\begin{array}{l}10-39.5 \\
44-77\end{array}$ & $\begin{array}{c}\text { BG (10YR 6/2) } \\
\text { G(10YR } 7 / 2)\end{array}$ & C & $\begin{array}{l}w S B \\
s S B\end{array}$ & $\begin{array}{l}\text { fsPS } \\
\text { P.S. }\end{array}$ \\
\hline Guimbalaon & $\begin{array}{l}A \\
B\end{array}$ & $\begin{array}{c}0-14 \\
14-40\end{array}$ & $\begin{array}{c}\mathrm{B}(10 \text { YR } 4 / 3) \\
\mathrm{s} 8(7.5 \text { YR } 5 / 6)\end{array}$ & C & $\begin{array}{c}m \mathrm{~m} \\
\mathrm{mSB}\end{array}$ & $\begin{array}{l}\text { fsPS } \\
\text { fsPS }\end{array}$ \\
\hline Himayangan & $\begin{array}{l}A \\
B\end{array}$ & $\begin{array}{c}0-15 \\
15-31\end{array}$ & $\begin{array}{c}\mathrm{B}(2.5 Y 4 / 4) \\
\mathrm{B}(2.5 \times 4 / 4)\end{array}$ & C & $\begin{array}{l}m g \\
s S B\end{array}$ & $\begin{array}{l}\text { PS } \\
\text { PS }\end{array}$ \\
\hline LaPaz & $\begin{array}{l}A \\
B\end{array}$ & $\begin{array}{c}0-12 \\
12-23\end{array}$ & $\begin{array}{l}v d G(5 Y 3 / 1) \\
\operatorname{vd} G(5 Y 3 / 1)\end{array}$ & SL & $\begin{array}{l}\mathrm{mP} \\
\mathrm{sP}\end{array}$ & $\begin{array}{l}\text { PNS } \\
P S\end{array}$ \\
\hline Langa & $\begin{array}{l}\text { A } \\
\text { B. }\end{array}$ & $\begin{array}{c}0-36 \\
36 \text { below }\end{array}$ & $\begin{array}{r}\text { By (10YR 6/8) } \\
\cdots \quad \text { yB (10YR } 6 / 8)\end{array}$ & C & $\begin{array}{l}m S B \\
m S B\end{array}$ & $\begin{array}{l}P S \\
P S\end{array}$ \\
\hline Libon & $\begin{array}{l}A \\
B\end{array}$ & $\begin{array}{c}0-23 \\
23-43\end{array}$ & $\begin{array}{l}d G(5 Y R 4 / 1) \\
d G(5 Y R 4 / 1)\end{array}$ & SC & $\begin{array}{l}m G \\
m G\end{array}$ & $\begin{array}{l}\text { PS } \\
\text { fPS }\end{array}$ \\
\hline Lligo & $\begin{array}{l}\mathrm{A} \\
\mathrm{B}\end{array}$ & $\begin{array}{c}0-16 \\
56-78\end{array}$ & $\begin{array}{l}\mathrm{d} G(5 Y R 5 / 6) \\
\mathrm{d} G(5 Y R 3 / 2)\end{array}$ & C & $\begin{array}{l}w G \\
s S B\end{array}$ & $\begin{array}{l}P S \\
P S\end{array}$ \\
\hline Luisita & $\begin{array}{l}\mathrm{A} \\
\mathrm{B}\end{array}$ & $\begin{array}{c}0-23 \\
23-58\end{array}$ & $\begin{array}{l}\text { vdG(10YR3/2) } \\
\text { dyB (10YR 4/4) }\end{array}$ & $S$ & $\begin{array}{l}m G \\
w G\end{array}$ & $\begin{array}{c}\text { fsPS } \\
\text { fsNSNP }\end{array}$ \\
\hline Maasin & $\begin{array}{l}A \\
B\end{array}$ & $\begin{array}{c}0-6 \\
46-57\end{array}$ & $\begin{array}{l}\text { dB }(7.5 Y R 3 / 4) \\
\text { s B }(7.5 Y R 5 / 6)\end{array}$ & C & $\begin{array}{l}w G \\
w G\end{array}$ & $\begin{array}{c}\text { fs NSNP } \\
\text { IsPS }\end{array}$ \\
\hline Macolod & $\begin{array}{l}\mathrm{A} \\
\mathrm{B}\end{array}$ & $\begin{array}{c}0-21 \\
21-36\end{array}$ & $\begin{array}{r}\text { vdG }(10 Y R 2 / 0) \\
\text { vdG(10YR } / 0)\end{array}$ & SL & $\begin{array}{l}W G \\
W G\end{array}$ & $\begin{array}{c}\text { PS } \\
\text { NS NP }\end{array}$ \\
\hline Malilibog & $\begin{array}{l}\mathrm{A} \\
\mathrm{B}\end{array}$ & $\begin{array}{l}24-31 \\
31-52 \\
\end{array}$ & $\begin{array}{r}\mathrm{vdGB}(10 \mathrm{YR} / 2) \\
8(10 \mathrm{YR} / 3)\end{array}$ & C & $\begin{array}{l}m S B \\
m S B\end{array}$ & $\begin{array}{l}P S \\
P S \\
\end{array}$ \\
\hline
\end{tabular}


Table 1. (Cont'd)

\begin{tabular}{|c|c|c|c|c|c|c|}
\hline \multirow[t]{2}{*}{ Mayoyao } & A & $0-23$ & $B(2.5 Y R 4 / 4)$ & C & $W G$ & fsPS \\
\hline & B & $77-107$ & $\mathrm{dGB}(2.5 Y 4 / 2)$ & & $\mathrm{mSB}$ & PS \\
\hline \multirow[t]{2}{*}{ Mayon } & A & $0-37$ & $\mathrm{~dB}(7.5 Y \mathrm{Y} 4 / 4)$ & SL & wB & NPNS \\
\hline & $B$ & $37-66$ & B (7.5 YR 4/2) & & w SB & NPNS \\
\hline Medellin & $\begin{array}{l}A \\
B\end{array}$ & $\begin{array}{c}0-15 \\
37 \\
\text { below }\end{array}$ & $\begin{array}{l}\text { dGB(10YR 4/2) } \\
\text { dyB (10YR 4/4) }\end{array}$ & c & $\begin{array}{l}\text { W SB } \\
\text { s SB }\end{array}$ & $\begin{array}{l}\text { PS } \\
\text { PS }\end{array}$ \\
\hline Palo & A & 0.19 & dRB (5YR A/4) & $\mathrm{CL}$ & $m A B$ & PS \\
\hline Palompon & $\begin{array}{l}\text { A } \\
B\end{array}$ & $\begin{array}{c}0-17 \\
28-35\end{array}$ & $\begin{array}{l}\text { sB (7.5YR 5/6) } \\
\text { sB B (7.5YR 5/8) }\end{array}$ & C & $\begin{array}{l}\text { SB } \\
\text { SB }\end{array}$ & $\begin{array}{l}\text { fPS } \\
\text { fPS }\end{array}$ \\
\hline Pili & $\begin{array}{l}\mathrm{A} \\
\mathrm{B}\end{array}$ & $\begin{array}{c}0.4 \\
24-41\end{array}$ & $\begin{array}{l}\text { vdGB(10YR 5/8) } \\
\text { vdG(10YR 3/1) }\end{array}$ & C & $\begin{array}{c}\mathrm{sSB} \\
\mathrm{mB}\end{array}$ & $\begin{array}{l}\text { fPS } \\
\text { PS }\end{array}$ \\
\hline \multirow[t]{2}{*}{$\begin{array}{l}\text { Rough } \\
\text { Mountain }\end{array}$} & A & $0-16$ & $R G(5 Y R 4 / 4)$ & C & $S G$ & fPS \\
\hline & B & $16-46$ & $\mathrm{RB}(5 Y R 5 / 4)$ & & $S S B$ & fPS \\
\hline Taal & $\begin{array}{l}A \\
B\end{array}$ & $\begin{array}{c}0-24 \\
24-41\end{array}$ & $\begin{array}{l}\text { VdGB (10YR /2) } \\
\text { vdG (10YR 3/1) }\end{array}$ & $\mathrm{SL}$ & $\begin{array}{l}\mathrm{SSB} \\
\mathrm{mB}\end{array}$ & $\begin{array}{l}\text { FPS } \\
\text { PS }\end{array}$ \\
\hline Tacloban & $\begin{array}{l}A \\
B\end{array}$ & $\begin{array}{c}0.34 \\
34-60\end{array}$ & $\begin{array}{r}\text { Ry }(7.5 \text { YR } 6 / 8) \\
\text { Ry } 7.5 \text { YR 6/8) }\end{array}$ & C & $\begin{array}{l}m \mathrm{mSB} \\
\mathrm{s} S B\end{array}$ & $\begin{array}{l}\text { PS } \\
\text { PS }\end{array}$ \\
\hline Tigaon & $\begin{array}{l}\text { A } \\
\text { B }\end{array}$ & $\begin{array}{r}0-20 \\
42-61 \\
\end{array}$ & $\begin{array}{l}\operatorname{vdB}(7.5 Y R 3 / 0) \\
\operatorname{vdB}(7.5 Y R 2 / 0)\end{array}$ & C & $\begin{array}{l}m G \\
s B\end{array}$ & $\begin{array}{l}\text { PS } \\
\text { PS }\end{array}$ \\
\hline
\end{tabular}

Legend:

Color
d-dark
s-strong
vd-very dark
vd-very dark
y-yellowish
B-brown
G-gray
R-red

Structure

w-weak

$\mathrm{m}$-moderate

s- strong

G- granular

$\mathrm{SB}$ - sub - angular blocky

$\mathrm{AB}$ - angular blocky

\section{Consistence}

$f$-friable

s- soft

P-plastic

S-sticky

NP - nonplastic

NS - Nonsticky

Volcanic ash soils are defined as those soils having andic properties to a depth of $35 \mathrm{~cm}$ or more from the surface and having a mollic or an umbic horizon possibly overlying a cambic horizons. These soils are formed from volcano clastic material and normally they exhibited a color hue of 7.5YR to 10 YR with color descrintions of black, dark brown, brownish black, and brown. The volcanic ash soil samples in this research were laken from the Bicol Region and they are represented by 
the following soil series: Casugiran, Castilla, Mayon, Pili, and San Manuel.

Generally, Red-Yellow soils with low base saturation are characterized as infertile soils which have very low soil pH and high amounts of exchangeable $\mathrm{Al}$ and $\mathrm{Fe}$ due to the abundance of iron oxides primarily hematite and goethite (Bautista-Tulin 1995). These minerals are responsible for the red and yellow colors in soils. Dark colored soils, on the other hand, indicate the presence of high amounts of organic matter and humus which make the soil more suitable for rootcrop production.

\section{Soil Structure}

Soil structure is characterized by the spatial arrangement of soil particles and the water and pore spaces into different positions (Schlichting et al. 1995 as cited by Asio 1996) or into secondary particles, units or peds. This property also indicates the suitability of soils for root crop production. The granular structure for instance is due to the very high humus content (16\%) in the surface horizon while the angular blocky structure is probably due to the crystalline material. Table 1 presents the various structures exhibited by Red-Yellow and Volcanic ash soils which include the following: granular, subangular blocky, blocky, and prismatic structures. Normally soils would exhibit different types of structures within the soil profile which could be used also as a differentiating characteristic for each horizon.

The stability of soll structure could also be attributed to the presence of organic matter which acts as a cementing agent for soil particles. A very strong soil structure such as those of the strong granular and strong angular blocky structure of clayey soils are not so good for root crops because of its penetration resistance. For rootcrops, especially for sweetpotato, the most critical stage of the growth cycle in terms of root yield is the stage of root initiation or tuberization (Bleeker and Alpine 1984). For a 24-week growh cycle, tuber initiation is virtually complete by the eight week after 
planting (Wilson 1982). During the first eight weeks after planting, adverse environmental influences can lead to the development of non-tuberous rather than tuber-bearing root types, resulting in serious reduction in yield. Factors that inhibit tuberization or storage root development include waterlogged soils, dry and compact soils, high levels of nitrogen, and long day length. In contrast, high potassium, well-aerated friable soils, low temperatures, and short day length encourage tuber initiation (Wilson, 1982). Thus, the role attributed to soil structure on the growth of root crops is very critical especially at the onset of storage root development. Some of the soil morphological properties that are limiting to rootcrops include those with very strong degree of structure, high clay content, and high plastic consistency. In terms of soil structure, some soil series that are posing constraints to rootcrops development include Tigaon, Pill, Faraon, Lugo, Catbalogan series. These soils have very high clay content which would make the soils highly compact.

\section{Soll Consistence}

Soil consistence comprises the attributes of soil material that are expressed by the degree and kind of cohesion and adhesion or by the resistance to deformation or rupture. Although consistence and structure are interrelated, structure deals with the shape, size, and definition of natural aggregates that results from variations in the forces of attraction within a soil mass, whereas consistence deals with the strength and nature of such forces themselves. This property is commonly used to describe the "feel" of the soil and includes soil properties such as friability, plasticity, stickiness and resistance to compression, and shear, all of which have obvious importance for cultivation (Landon 1991). A good consistence that is suitable for root crop production include those of the Volcanic Ash soils which are friable, soft, non-sticky, and non-plastic since they are favorable for the development of tuberous roots. The list of rootcrop soils that belong to this category includes those from the Bicol Region which include the Casugiran, Castilla, Mayon, Macolod, Libon, Tigaon, and Pili Series. The Red-Yellow soils, on the other hand, are characterized by high clay content which showed high degree of plasticity and stickiness and would pose a 
major constraint on the growth and development of tuberous/storage roots. These include the Annam, Maasin, Catbalogan, Tacloban, Palo, and Bolinao series.

\section{Physical Characteristics of Rootcrop Soils}

The various physical properties (clay content, \% porosity, and moisture content at field capacity) of Red-Yellow and Volcanic Ash soils that are planted to rootcrops are presented in Table 2 .

\section{Clay Content}

Some of the physical properties of these highly weathered soils that are unfavorable for rootcrop production include the high clay content of the soils which would result to highly compacted soils. This is very common among the Red-Yellow soils especially in the upland and mountainous areas where rootcrops are commonly grown. This would inhibit the tuberization of sweetpotato thereby, affecting its yield (Aganon and Bautista-Tulin 1998). The various rootcrop soils which exhibited very high clay content $>50 \%$ clay either in the A or $B$ horizon) include the following soil series: Annam, Bolinao, Castilla, Casugiran, Faraon, Guimbalaon, Lugo, Mandaue, and Medellin.

\section{Percent medium porosity}

Porosity refers to the volume of pores in a soil sample (non solid volume) divided by the bulk volume of the sample. Pore size distribution, on the other hand, refers to the volume fractions of the various size ranges of pores in a soil, expressed as percentages of the soil bulk volume (soil particles plus pores). Percent medium porosity refers to the volume of medium pores in the soils. Results presented in Table 2 showed that most of the Red-Yellow and Voicanic ash soils planted to rootcrops have very low amounts of medium pores $(<20 \%)$ which could be attributed to the high amounts of clay that tend to reduce the volume of macropores in the soil. This causes a major constraint in the growth and development of primary and secondary roots thereby affecting the root yield. 
The different soil series with very low $\%$ medium porosity $(<10 \%)$ include the following: Annam, Bantog, La Paz, Luisita, Maasin, Malitbog, Mayon, Taal, and Tigaon series.

Table 2. Some physical properties of the A and B horizon of the Red-Yellow and Volcani Ash soils planted to rootcrops in the Philippines

\begin{tabular}{|c|c|c|c|c|c|}
\hline $\begin{array}{c}\text { Soil } \\
\text { Series }\end{array}$ & $\begin{array}{c}\text { Soil } \\
\text { Horizon }\end{array}$ & $\begin{array}{l}\text { Depth } \\
(\mathrm{cm})\end{array}$ & $\%$ Clay & $\begin{array}{c}\% \\
\text { Porosity }\end{array}$ & $\begin{array}{l}\% \text { Field } \\
\text { Capacity }\end{array}$ \\
\hline \multirow[t]{2}{*}{ Alaminos } & $A$ & $0-18$ & 12.21 & $17-72$ & 22.86 \\
\hline & B & $18-60$ & 23.96 & 30.44 & 39.91 \\
\hline \multirow[t]{2}{*}{ Annam } & A & $0-20$ & 44.54 & 16.50 & 32.47 \\
\hline & $B$ & $20-43$ & 59.05 & 18.00 & 40.60 \\
\hline \multirow[t]{2}{*}{ Bantay } & A & $0-18$ & 41.63 & 25.03 & trace \\
\hline & B & $37-68$ & 16.13 & 23.40 & trace \\
\hline \multirow[t]{2}{*}{ Bantog } & A & 0.21 & 23.13 & 19.72 & 34.78 \\
\hline & B & $36-64$ & 12.74 & 15.60 & 14.79 \\
\hline \multirow[t]{2}{*}{ Banyan } & A & $0-16$ & 25.94 & 31.50 & 38.13 \\
\hline & $B$ & below 27 & 28.79 & 35.00 & 44.02 \\
\hline \multirow[t]{2}{*}{ Bauang } & A & 0.9 & & 27.73 & 37.89 \\
\hline & B & $9-36$ & & 36.59 & 44.52 \\
\hline \multirow[t]{2}{*}{ Bolinao } & A & $0-23$ & 74.68 & 20.85 & 32.92 \\
\hline & B & $23-42$ & 86.20 & 24.04 & 42.11 \\
\hline \multirow[t]{2}{*}{ Castilla } & A & $0-12,50$ & 57.02 & 17.50 & 30.36 \\
\hline & B & 50 below & 70.42 & 24.00 & 39.56 \\
\hline \multirow[t]{2}{*}{ Casugiran } & A & $0-9$ & 34.69 & 19.00 & 30.93 \\
\hline & $B$ & $31-100$ & 72.08 & 27.50 & 41.74 \\
\hline \multirow[t]{2}{*}{ Catbalogan } & A & $0-6$ & 41.77 & 35.50 & 41.49 \\
\hline & $B$ & $17-34$ & 40.63 & 32.00 & 40.68 \\
\hline \multirow[t]{2}{*}{ Faraon } & A & $10-39.50^{\circ}$ & 52.87 & 27.29 & 44.00 \\
\hline & B & $44-77$ & 17.16 & 31.26 & 62.44 \\
\hline \multirow[t]{2}{*}{ Guimbalaon } & A & $0-14$ & 55.92 & 25.12 & 32.92 \\
\hline & $B$ & $14-40$ & 59.84 & 27.27 & 39.66 \\
\hline \multirow[t]{2}{*}{ Himayangan } & A & $0-15$ & 27.63 & 26.79 & 40.43 \\
\hline & B & $15-31$ & 31.83 & 25.47 & 43.75 \\
\hline \multirow[t]{2}{*}{ LaPaz } & A & 0.12 & 11.17 & 17.50 & 33.79 \\
\hline & B & $12-23$ & 15.50 & 18.50 & 35.73 \\
\hline
\end{tabular}


Table 2. (Cont'd)

\begin{tabular}{|c|c|c|c|c|c|}
\hline $\begin{array}{c}\text { Soli } \\
\text { Series }\end{array}$ & $\begin{array}{c}\text { Soil } \\
\text { Horizon }\end{array}$ & $\begin{array}{c}\text { Depth } \\
\text { (cm) }\end{array}$ & $\%$ Clay & $\begin{array}{c}\% \\
\text { Porosity }\end{array}$ & $\begin{array}{l}\% \text { Field } \\
\text { Capacity }\end{array}$ \\
\hline \multirow[t]{2}{*}{ Langa } & $A$ & $0-36$ & 39.50 & 19.30 & $\mathrm{Nd}$ \\
\hline & $\mathrm{B}$ & $\begin{array}{c}36-142 \\
\text { below }\end{array}$ & 13.79 & 18.60 & Nd \\
\hline \multirow[t]{2}{*}{ Libon } & A & $0-23$ & 22.59 & 8.25 & 34.05 \\
\hline & B & $23-43$ & 4.21 & 11.25 & 26.19 \\
\hline \multirow[t]{2}{*}{ Libon } & A & 0.23 & 22.59 & 8.25 & 34.05 \\
\hline & 8 & $23-43$ & 4.21 & 11.25 & 26.19 \\
\hline \multirow[t]{2}{*}{ - Lugo } & A & $0-16$ & 58.56 & 14.30 & 51.94 \\
\hline & $B$ & $56-78$ & 76.69 & 15.02 & 53.33 \\
\hline \multirow[t]{2}{*}{ Luisita } & A & $0-23$ & 4.59 & 6.25 & 13.86 \\
\hline & $B$ & $23-58$ & 5.42 & 6.25 & 11.50 \\
\hline \multirow[t]{2}{*}{ Maasin } & A & $0-6$ & 23.58 & 7.47 & 16.60 \\
\hline & $\mathrm{B}$ & $46-57$ & 41.26 & 6.87 & 24.46 \\
\hline \multirow[t]{2}{*}{ Macolod } & A & $0-21$ & 0.14 & 14.25 & 38.29 \\
\hline & $B$ & $21-36$ & 0.73 & 10.50 & 35.24 \\
\hline \multirow[t]{2}{*}{ Maitibog } & $A$ & $24-31$ & 29.44 & 9.60 & 34.32 \\
\hline & B & $31-52$ & 43.74 & 16.04 & 44.64 \\
\hline \multirow[t]{2}{*}{ Mandaue } & A & $0-11$ & 49.69 & 14.06 & 39.64 \\
\hline & $B$ & $24-59$ & 38.70 & 14.39 & 49,00 \\
\hline \multirow[t]{2}{*}{ Mayoyao } & A & $0-23$ & 9.77 & 14.64 & $\mathrm{Nd}$ \\
\hline & $B$ & $77-107$ & 12.06 & 13.49 & $\mathrm{Nd}$ \\
\hline \multirow[t]{2}{*}{ Mayon } & A & $0-37$ & 6.44 & 6.50 & 12.94 \\
\hline & $B$ & $37-66$ & 0.97 & 2.00 & 5.29 \\
\hline \multirow[t]{2}{*}{ Medelin } & A & 0-15 & 54.94 & 17.13 & 63,41 \\
\hline & 8 & 37 below & 44.95 & 17.88 & 73.96 \\
\hline \multirow[t]{2}{*}{ Palo } & A & $0-19$ & 13.86 & 18.42 & 44.25 \\
\hline & $B$ & $19-35$ & 18.31 & 16.68 & 39.88 \\
\hline \multirow[t]{2}{*}{ Palompon } & A & $0-17$ & 35.23 & 13.77 & 41.14 \\
\hline & $B$ & $28-45$ & 16.85 & 14.23 & 35.75 \\
\hline \multirow[t]{2}{*}{ Pili } & A & $0-4$ & 38.04 & 9.75 & 36.64 \\
\hline & B & 24.41 & 40.29 & 13.25 & 35.65 \\
\hline \multirow{2}{*}{$\begin{array}{c}\text { Rough } \\
\text { Mountainous Land }\end{array}$} & A & $0-16$ & 32.45 & 14.25 & 37.51 \\
\hline & $B$ & $16-46$ & 25.48 & 13.50 & 34.20 \\
\hline \multirow[t]{2}{*}{ San Miguel } & A & $0-32$ & 40.06 & 13.07 & $\mathrm{Nd}$ \\
\hline & $\mathrm{B}$ & $32-50$ & 20.62 & 14.66 & $\mathrm{Nd}$ \\
\hline
\end{tabular}


Table 2 (cont'd).

\begin{tabular}{cccccc}
\hline $\begin{array}{c}\text { Soil } \\
\text { Series }\end{array}$ & $\begin{array}{c}\text { Soll } \\
\text { Horizon }\end{array}$ & $\begin{array}{c}\text { Depth } \\
\text { (cm) }\end{array}$ & \% Clay & $\begin{array}{c}\% \\
\text { Porosity }\end{array}$ & $\begin{array}{c}\text { \% Field } \\
\text { Capacity }\end{array}$ \\
\hline Taal & A & $0-24$ & 24.53 & 9.86 & 25.80 \\
& B & $24-25$ & 31.48 & 9.07 & 25.94 \\
Tacloban & A & $0-34$ & 19.88 & 10.13 & 33.33 \\
& B & $34-60$ & 29.29 & 13.53 & 40.98 \\
Tigaon & A & $0-20$ & 13.49 & 9.25 & 19.47 \\
& B & $42-61$ & 16.90 & 9.75 & 23.81 \\
Umingan & A & $0-13$ & 37.38 & 10.31 & 32.38 \\
& B & $13-25$ & 41.75 & 11.36 & 37.23 \\
\hline
\end{tabular}

\section{Water content at field capacity (F.C.)}

Table 2 presents the water contents at $1 / 3$ bar tension which refers to the water-holding capacity of the soil. The capacity of soil to retain water determines the amount of moisture that will be available to the roots and soil organisms. It has direct meaning to the amount of moisture available for chemical weathering as well as for nutrient availability to plants. The latter is of great significance to rootcrops since this will facilitate the availability of nutrients that will be absorbed by the plant roots. Results showed that generally, Red-Yellow soils have higher moisture contents due to the high amounts of clay present in the soil which could retain available moisture on its surfaces. Soils with higher \% F.C. $(>40 \%)$ include the following soil series: Lugo, Malitbog, Medellin, Palo, Palompon, Annam, Banyan, Bauang, Casugiran, Catbalogan, Faraon, Himayangan, Mandaue, and Tacloban series.

High clay contents soils also have high surface areas which could retain more nutrients on their surfaces. However, this advantage is offset by the degree of compaction that the high amounts of clay will contribute to the soil. Sweetpotato yield is reduced when soil compaction is too high or too low (Sajjapongse and Roan 1982). 
Another important physical property of the soils that would limit the growth and development of rootcrops include the degree of stoniness and shallowness of the soil since this will greatly affect root expansion and deprive the soil of important nutrients needed by the plant. Likewise, the loss of the top few millimeters of soil due to erosion in highly weathered soils where organic matter and biological activity are concentrated is also detrimental to the crop since this will lead to the deterioration of soil fertility and crop yields, as well as the soil's water- holding capacity. Often these unfavorable soil physical conditions such as compaction, restriction in porosity, restricted drainage, and others coupled with weed proliferation lead to significant decreases in crop yield (Aganon and Bautista-Tulin 1998). In addition, structural deterioration of the soil is usually associated with the decrease in organic matter which leads to low available nutrients in the soil.

\section{Chemical Characteristics of Rootcrop Soils}

Table 3 presents the important chemical properties of Red-Yellow and Volcanic ash soils planted to rootcrops. The chemical properties of RedYellow and Volcanic ash soils that are greatly affecting the growth and development of rootcrops include the soil $\mathrm{pH}, \%$ O.M. amount of exchangeable aluminum, exchangeable bases such as potassium, calcium and magnesium, and available phosphorus.

\section{Soil $\mathrm{pH}$}

The $\mathrm{pH}$ of the samples was determined using $\mathrm{H}_{2} \mathrm{O}, 1 \mathrm{~N} \mathrm{KCl}, 0.01 \mathrm{M}$ $\mathrm{CaCl}_{2}$ and $1 \mathrm{~N} \mathrm{NaF}$. The $\mathrm{pH}$ in $\mathrm{KCl}$ was used since this is important in the determination of delta $\mathrm{pH}$ which is an indicator of the charge characteristics of soils (Tulin 2000) and this is an important parameter for Red-Yellow and volcanic ash soils. The $\mathrm{pH}$ in $0.01 \mathrm{M} \mathrm{CaCl}_{2}$, on the other hand, could estimate the electrolytic composition of soil solutions found at optimum moisture conditions for plant growth in non-saline soils (Asio 1996). The $\mathrm{N}$ $\mathrm{NaF}$ was determined as an indication of the predominance of exchange complex dominated by amorphous materials for volcanic ash soils (ICOMAND 1979) although this parameter was found to be a not reliable 


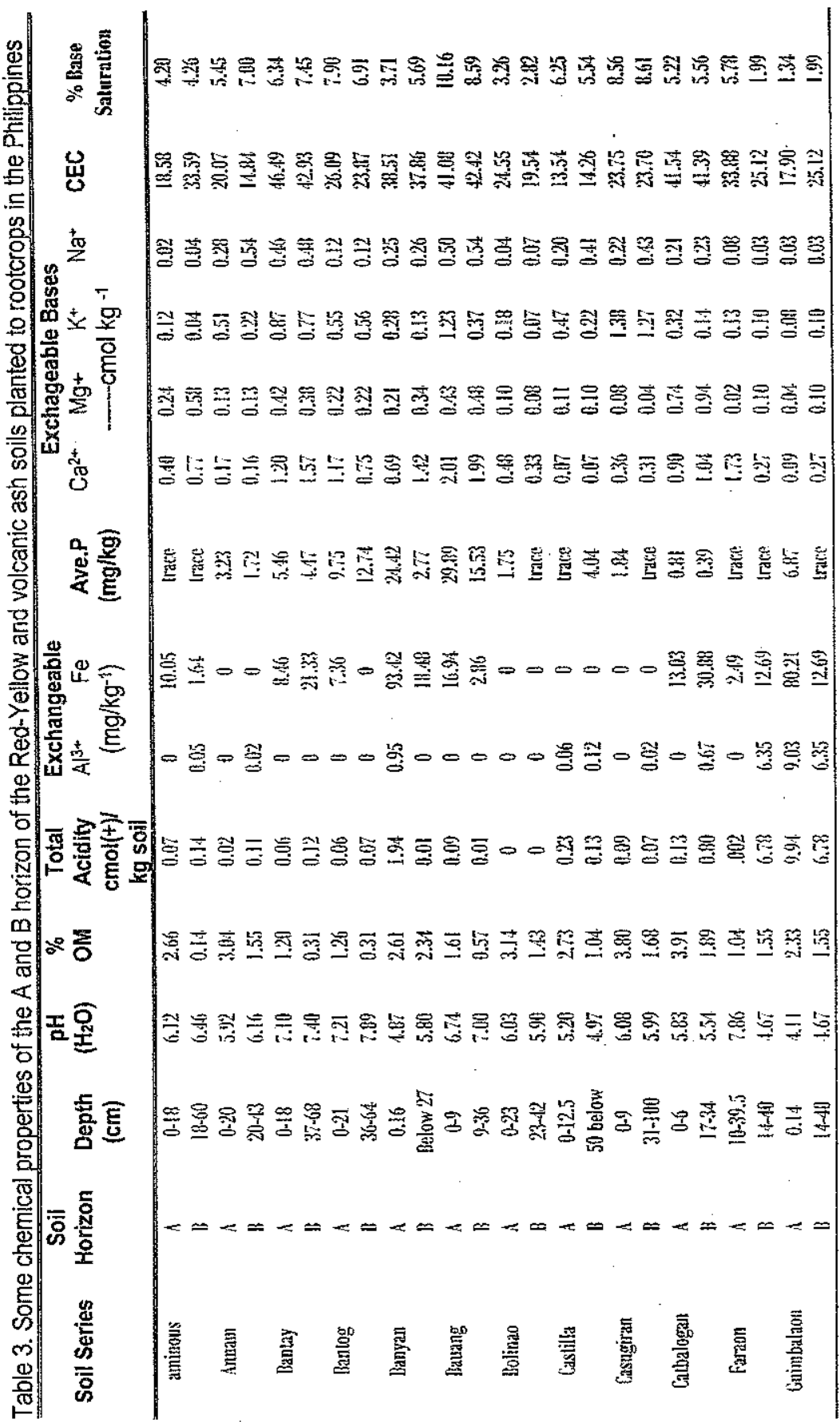




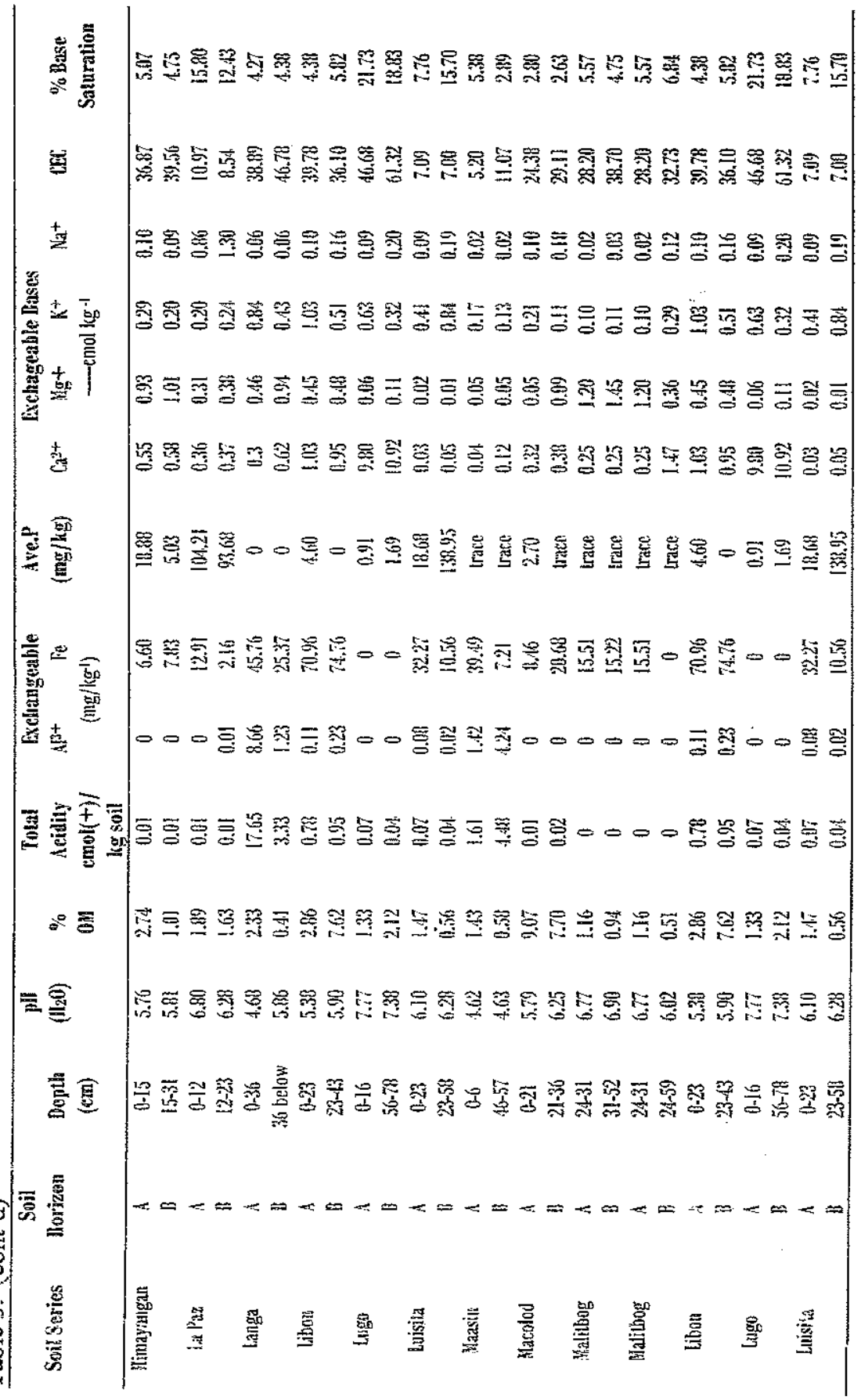




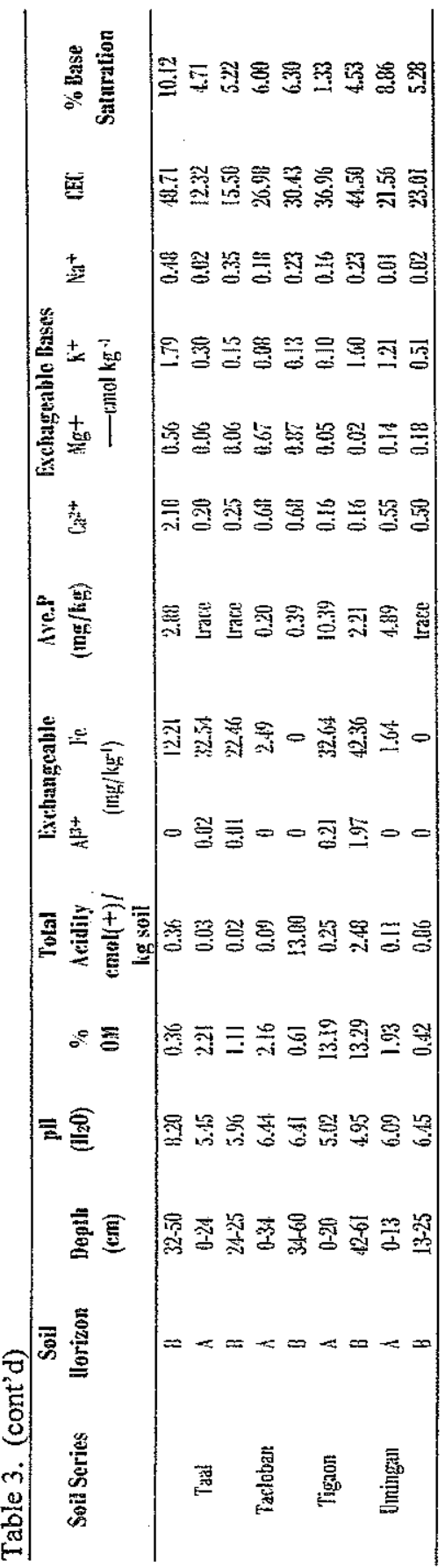


property as a differentiating criterion for Andisols (ICOMAND 1983). However, some researchers reported the usefulness of this parameter in characterizing volcanic ash soils (Mizota and van Reeuwijk 1989).

Samples which have a soil pH of $<6.0$ in $\mathrm{H}_{2} \mathrm{O}, \mathrm{KCl}$, and $\mathrm{CaCl}_{2}$ include the following: Casiguran, Castilla, Mayon, Annam,Macolod, Tigaon, Banyan, Rough mountainous land, San Manuel, Catbalogan, Palompon, Taal, Himayangan, Maasin, Bolinao, Guimbalaon, and Langa soil series. From these data, it is apparent that soil pH could greatly affect the development of rootcrops in the said areas since it is related to the availability of nutrients in the soll. Soils with low pH are usually infertile due to low amounts of exchangeable bases and high concentrations of $\mathrm{Fe}$ and $\mathrm{Al}$ which are detrimental to plants.

\section{Organic Matter (OM)}

Organic matter is one of the most important chemical properties of soils that would determine their fertility status because aside from improving the physical properties of soils by encouraging granulation, it will also release available nutrients to the soil upon microbial decomposition. Soils high in organic matter content are generally fertile. OM values also determine the amounts of organic carbon and mineralizable $\mathrm{N}$ that could be derived from the soils. There is a strong positive correlation between \%OM and the amounts of organic carbon and mineralizable $\mathrm{N}$ in the soils.

Results presented in Table 3 showed that most of the Red-Yellow soils surveyed have very low amounts of organic matter and this tend to decrease with depth. Generally, surface soils have high amounts of OM decreases in the subsurface layers. This is evident in all the soils sampled. Considering the important role played by $O M$ in crop production, there is a great need to increase the amounts of OM in RedYellow soils to make them more productive and suitable for rootcrops. 


\section{Exchangeable Aluminum and Iron}

Exchangeable aluminum is an important property of Red-Yellow soil and it is often one of the major limiting factors to crop growth in acid soils. It has been reported that crop growth in acid soils is correlated with aluminum saturation or concentration in soil solution (Adams, 1984 as cited by Asio, et al., 1996). Aside from Al, Red-Yellow soils also contain high amount of iron usually in the form of goethite, ferrihydite, and other iron oxides (Theng, 1980). Results showed that soils with very low pH are Guimbalaon, Langa, Maasin, Palompon, Rough mountainous land, and Tigaon series. Asio et al., (1992), reported that exchangeable $\mathrm{A}^{\mathrm{\beta}+}$ tends to increase considerably below pH 5.0 in $\mathrm{H}_{2} \mathrm{O}$ and $\mathrm{pH} 4.0$ in $\mathrm{CaCl}_{2}$ at $1: 1$ soil.

\section{Available Phosphorous (P)}

Another important chemical property of the Red-Yellow and Volcanic ash soil that is limiting for rootcrop production is the amount of available phosphorus in the soil. Next to N,P is the second major growth-limiting factor for plants. This is probably the most deficient soil-derived nutrient in Red-Yellow and Volcanic ash soils.

Results showed that most of the soils sampled are generally deficient in this nutrient especially for the volcanic ash soils which have the ability to fix high amounts of $P$ in the soils. Soils series with very low amounts of $P$ include the following: Alaminos, Bolinao, Castilla, Casiguran, Catbalogan, Faraon, Langa, Lugo, Maasin, Macolod, Malitbog, Mandaue, Medellin, Palo, Palompon, Tacloban, and Taal series.

\section{Exchangeable Bases and CEC}

Results showed that generally all the soils sampled have very low amount of exchangeable bases ( $\mathrm{Ca}, \mathrm{Mg}, \mathrm{K}$, and $\mathrm{Na}$ ). This is very evident in the acidic Red-Yellow soils since basic cations abound mostly under near neutral or alkaline conditions. One of the most important basic cations that is needed by rootcrops is potassium since this is important in the 
development of tuberous roots. $\mathrm{Ca}$ and $\mathrm{Mg}$ are also important for rootcrops considering the various physiological functions they perform in plants.

CEC is another important factor to consider in determining the properties of Red-Yellow and Volcanic ash soils. Results showed that most of our soils have very low CEC values and this implied that the soils are generally infertile. These findings were supported by the very low amounts of exchangeable bases that were determined. Soil series which exhibited very low CEC values $\left(<20 \mathrm{cmol} \mathrm{kg}^{-1}\right)$ are the following: Annam, Castilla, Guimbalaon, La Paz, Luisita, Maasin, Rough mountainous land, and Taal series.

\section{Soil Constraints for Some Red-Yellow Soils in Region VIII}

To give a clearer picture of some of the chemical constraints for some Red-Yellow and highly weathered soils planted to rootcrops in Region VIII, an attempt was done by characterizing these surveyed soils using Geographical Information System (GIS). Results showed some of the chemical properties determined and their percent distribution in Region VIII with emphasis on the Leyte island. The various GIS generated maps on these properties showed a clear evidence that the soils in Region VIII that are planted to rootcrops are indeed very infertile and effective management strategies should be included for these solls to make them more productive for rootcrops. Some of the identified soil constraints to rootcrop production in Region VIII include the very low soil pH of most of the Red-Yellow soils in the region and low amounts of $\mathrm{OM}$, and exchangeable bases, with low amount of $P$ in most soils.

\section{Implications to Soil Management}

This research has shown that Red-Yellow soils have low soil pH $(<6.0)$, low amount of $N$, very low amounts of exchangeable bases, high amount of $\mathrm{Al}$ and exchange acidity, and low amount of organic matter. Some of the major chemical constraints associated with Red-Yellow and Volcanic ash soils grown to rootcrops in the Philippines include: low organic matter content, soil acidity, Al toxicity, low nutrient reserves, especially 
$\mathrm{N}, \mathrm{Ca}, \mathrm{Mg}$, and $\mathrm{K}$, low $\mathrm{P}$ availability due to fixation in Andisols, and high degree of leaching of essential nutrients caused by excessive rainfall. It should be noted that most of the Red-Yellow soils gathered were those in the upland and mountainous areas which make them vulnerable to soil erosion. This condition causes the reduction of the topsoil and biomass concentration thereby, reducing the amount of soil organic matter that is exposed to enhance the various chemical, physical, and morphological characteristics of the soil. Aside from this, biomass and ground litter contain important nutrients to rootcrops which are released in the soil through burning and decomposition. They also promote granulation and reduce soil compaction thereby, improving the physical properties of the soil. It should be noted that biomass production is a key in maintaining soil fertility. Thus, for Red-Yellow soils, organic matter management is therefore a very important strategy in making these soils productive for rootcrops.

One of the major soil constraints for crop production associated with volcanic ash soils include the very small amount of $P$ probably due to high $P$. fixing capacity of the soil. Most Andisols show very low $P$ fertility and very low response of applied $P$ fertilizers by crops (Shoji et al., 1993). To alleviate these constraints, large amount of $P$ fertilizers is usually applied to improve the soil chemical properties in order to create favorable conditions suitable for crop production. The results obtained by Bautista-Tulin et al. (1996) on the effect of applied $P$ on the chemical properties of Andisols showed that continuous addition of large amounts of $P$ fertilizers to a volcanic ash soil may contribute to alleviating the $P$ deficiency problem by increasing the amounts of available $P$ in soil. Likewise, such application may improve soil chemical properties by increasing the CEC and the amounts of exchangeable bases, which may result in the promotion of crop production.

\section{CONCLUSIONS AND RECOMMENDATIONS}

The results of this research showed strong evidence on the existence of morphological, physical, and chemical constraints in Red-Yellow and Volcanic Ash soils that are planted to rootcrops in large areas in the Philippines. This 
finding implied an urgent need to properly manage these soils to make them more productive for rootcrops. This poses a major challenge to researchers, extension workers, and development planners in designing suitable management strategies that will make these soils more suitable and productive to rootcops. The goal now should not only be limited to attain a sustainable production but should be focused more on attaining high productivity in terms of high yields to make rootcrops more competitive with other crops as well as to encourage more farmers to plant rootcrops. It is further recommended that more research activities be conducted with regard to the management of Red-Yellow soils and other problem soils to make them more suitable for rootcrop production.

\section{LITERATURE CITED}

AGANON, C. AND A. BAUTISTA-TULIN. 1998. Participatory approaches to integrated nutrient management in the Philippines. Sustainable Livelihood for Rural Households: Contributions from Rootcrop Agriculture. UPWARD, Los Banos, Laguna, Philippines. pp. 111-136.

ASIO, V.B. 1996. Characteristics, weathering, formation and degradation of solls from volcanic rocks in Leyte, Philippines. Hohenheimer Bodenkundliche Hefte 333. (Published PhD Dissertation, University of Hohenheim) Stuttgart, Germany.

ASlO, V.B., R. B. Armecin and A. T. Bautista. 1992. Relationships between exchangeable alumninum and $\mathrm{pH}$ in some acidic Philippine soils. The Phil. J. of Sci. 121: 383-390.

BAUTISTA, A. T. and R. ARMECIN. 1990. Survey of major root crop producing areas in the Philippines, and identification of yield potential based on previous studies conducted in these soils. Paper presented during PRCRTC in-house Review last March 8-9, 2003 at PRCRTC, ViSCA, Baybay, Leyte. 
BAUTISTA, A, T., and K. INOUE, 1993. Significance of loss addition in relation to Andic soil properties of volcanic ash soils. Soil Sci. Plant Nutr. 39:517-527

BAUTISTA-TULIN, A.T., A.M. BRIONES, and K. INOUE. 1996. Effect of $P$ application on CEC, amounts of extractable nutrients, and corn yield in a Hydric Melanudand in the Philippines. Soil Sci. Plant Nutr., 42: 383-387.

BAUTISTA-TULIN, A. T. and K. INOUE. 1997. Hydroxy-interlayered minerals in Japanese soils influenced by eolian deposition. Soil Sci. Soc. Am. J. 61: 631-640.

BAUTISTA - TULIN, A. T. 1995. Studies on the nature and properties of Red-Yellow and volcanic ash soils in the temperate and tropical regions. PhD. Dissertation. The United School of Agricultural Sciences. Iwate University, Japan. $173 \mathrm{pp}$.

BLEEKER, P. G. KEIG and J. R. Mc ALPINE. 1984. Soil resources, demography and land use : An example of steep. Land Problems in Papua New Guinea. In: Proceedings of the International Workshop on Soils. 12-16 September 1983. Townsville, Queensland, Australia. pp. 121-144.

BURINGH, P. 1989. Availability of agricultural land for crop and livestock production. In: D. Pimentel and C. W. Hall (eds.), Food and Natural Resources, pp. 70-85. Academic Press, San Diego.

FAO. 1980. Land Resources for Populations of the Future. Report on the second FAO/UNFPA Expert Consultation. Rome. FAO.

FAO. 1983. Guidelines: Land Evaluation for Rainfed Agriculture. Soil Bulletin no. 52. Rome. 249 pp.

HAMAZAKI, T. and E. P. PANINGBATAN, Jr. (Editors), 1988. Procedures for Soil Analysis. Department of Soil Science, University of the Philippines at Los Baños, Laguna. $94 \mathrm{pp}$.

HAMAZAKI, T. and E.P. PANINGBATAN, Jr. 1990. Data Base on RedYellow and Related Soils in the Philippines. Part 2: Visayas and Mindanao Soils, University of the Philippines at Los Baños, Laguna, Philippines and Tropical Agriculture Research Center, Japan, 104 pp. 
HOWELER, R. H. 1985. Mineral nutrition and fertilization of cassava. A Review of Recent Research. In J. H. Cook and J. A. Reyes, (Editors). Cassava: Research, Production and Utilization. CIAT, Cali, Colombia. pp. 249-3320.

ICOMAND 1979. International Committee on the Classification of Andisols, Circular Letter No. 1, New Zealand Soil Bureau, DSIR, Lower Hutt, 28pp.

ICOMAND 1983. International Committee on the Classification of Andisols, Circular Letter No. 5, New Zealand Soil Bureau, DSIR, Lower Hutt, 31pp.

ISRIC 1986. Procedures for Soil Analysis (L. P. Van Reeuwijk), Editor), P. O. Box 353,6700, AS, Wagenigen, The Netherlands., 106 pp.

MIZOTA, C. and L. P. van REEUWIJK. 1989. Clay Mineralogy and Chemistry of Solls formed in Volcanic Material in Diverse Climatic Regions. Soil Monograph 2, ISRIC, Wageningen.

LANDON, J. R. (Editor), 1991: Booker Tropical Soil Manual. Longman Scientific and Technical, England, $474 \mathrm{pp}$.

OTSUKA, H., BRIONES, A.A., DAQUIADO, N.P. and F.A. EVANGELIO. 1988. Characteristics and Genesis of Volcanic Ash Soils in the Philippines. Technical Bulletin Tropical Agriculture Research Center, 24: 1-122.

RASCO, E. T. Jr. and F. G. VILLAMAYOR, JR. 1986. Environmental requirements, nutrition and cultural management of sweetpotato. In: State of the Art: Sweetpotato Research. PCARRD, Los Baños, Laguna, Philippines. Crop Research Series No. 9. P 1220.

SAJJAPONGSE, A., and Y.C. ROAN. 1982. Physical factors affecting root yield of sweet potato. (Ipomea batatas (L) Law). In: Sweet Potato Proceedings of the First International Symposium. Eds. R. C. Villareal and T. P. Greggs.

SHOJI, S., M. NANZYO and R. A. DAHLGREN. 1993. Volcanic Ash Soils: Genesis, Properties and Utilization. Development in Soil Science 21, Elsevier, Amsterdam, $288 \mathrm{pp}$. 
SHENG, T. C. 1989. Soll Conservation for Small Farmers in the Humid Tropics. Bulletin no. 60. FAO, Rome. 104 pp.

SCOTT, G.J., R. BEST, M. ROSEGRANT, and M. BOKANGA. 2000. Roots and tubers in the global food system: A vision statement to the year 2020 . A co-publication of the International Potato Center (CIP), Centro International de Agricultura Tropical (CIAT), International Food Policy Research institute (IFPRI), International Institute of Topical Agriculture (IITA), and International Plant Genetic Resources Institute (IPGRI). Printed in Lima, Peru: International Potato Center.

SOIL SURVEY STAFF. 1993. Soil Survey Manual. U.S. Gov. Printing Office. No. 18. USDA. Washington, D.C.

THENG, B. K. G. 1980. Soils with Variable Charge. New Zealand Society of Soil Science. Offset Publication. N. Z. 448pp.

TULIN, A.B. 2000. Surface charge characteristics of selected Philippine solls. Ann. Trop. Res. 22[1\&2]:60-77.

TULIN, A.B., J. R. PARDALES, Jr., V. B. ASIO and D. M. CAMPILAN. 1999. Nutrient deficiency symptoms of sweetpotato varieties planted in degraded uplands of Pinabacdao, Samar and in commercial areas of Leyte and Samar. Paper presented during the $11^{\text {th }}$ Regional Symposium on Research and Development at VIC-MAR Beach Resort, San Jose, Tacloban, Philippines last September 11, 1999.

VILLAMAYOR, F. G. JR. and V. R. AMANTE. 2000. Sweetpotato in the upland agroecology of the Philippines. In: Sweet potato in tropical Asia (E.T. Rasco, Jr. and V.R. Amante, eds.) Book Series No. 169/2000. PCARRD. pp. 58-125.

WILSON, L. A. 1982. Tuberization in Sweet Potato (Ipomoea batatas (L) Lam). In: Sweetpotato Proceedings of the First International Symposium, eds., R. C. Villareal and T. D. Griggs. Taiwan: AVRDC. pp 79-94. 